\title{
ERa inhibits epithelial-mesenchymal transition by suppressing Bmi1 in breast cancer
}

\author{
Xiao-Long Wei ${ }^{1,2}$, Xiao-Wei Dou ${ }^{2}$, Jing-Wen Bai ${ }^{2}$, Xiang-Rong Luo ${ }^{2}$, Si-Qi Qiu ${ }^{3}$, \\ Di-Di Xi' ${ }^{2}$, Wen-He Huang ${ }^{3}$, Cai-Wen Du4 ${ }^{4}$ Kwan Man ${ }^{5}$, Guo-Jun Zhang ${ }^{2,3}$ \\ ${ }^{1}$ Department of Pathology, Cancer Hospital of Shantou University Medical College, Shantou 515031, China \\ ${ }^{2}$ Changjiang Scholar's Laboratory and Cancer Research Center, Shantou University Medical College, Shantou 515031, China \\ ${ }^{3}$ The Breast Center, Cancer Hospital of Shantou University Medical College, Shantou 515031, China \\ ${ }^{4}$ Department of Breast Medical Oncology, Cancer Hospital of Shantou University Medical College, Shantou 515031, China \\ ${ }^{5}$ Department of Surgery and Transplantation, Li Ka Shing Faculty of Medicine, Hong Kong University, Hong Kong 999077, \\ China
}

Correspondence to:

Guo-Jun Zhang, e-mail: guoj_zhang@yahoo.com

Keywords: ERa signaling, epithelial-mesenchymal transition, Bmil, breast cancer, stemness

Received: October 202014

Accepted: April 30, 2015

Published: May 13, 2015

\section{ABSTRACT}

In human breast cancer, estrogen receptor- $a(E R a)$ suppresses epithelialmesenchymal transition (EMT) and stemness, two crucial parameters for tumor metastasis; however, the underlying mechanism by which ERa regulates these two processes remains largely unknown. Bmi1, the polycomb group protein B lymphoma Mo-MLV insertion region 1 homolog, regulates EMT transition, maintains the selfrenewal capacity of stem cells, and is frequently overexpressed in human cancers. In the present study, ERa upregulated the expression of the epithelial marker, E-cadherin, in breast cancer cells through the transcriptional down-regulation of Bmi1. Furthermore, ERa overexpression suppressed the migration, invasion, and EMT of breast cancer cells. Notably, overexpression of ERa significantly decreased the CD44 ${ }^{\text {high }} / \mathrm{CD}^{2} 4^{\text {low }}$ cell population and inhibited the capacity for mammosphere formation in ERa-negative breast cancer cells. In addition, overexpression of Bmi1 attenuated the ERa-mediated suppression of EMT and cell stemness. Immunohistochemistry revealed an inverse association of $\mathrm{ER} a$ and $\mathrm{Bmi1}$ expression in human breast cancer tissue. Taken together, our findings suggest that ER $a$ inhibits EMT and stemness through the downregulation of Bmi1.

\section{INTRODUCTION}

Of all cancers, that of the breast is the most common for women, with most breast cancer-related deaths involving widespread metastasis [1]. Estrogen receptor- $\alpha(E R \alpha)$ is a nuclear receptor that is activated by the sex hormone, estrogen; it regulates the transcription of estrogen-responsive genes in diverse target cells. Ligand binding induces a conformational change within $E R \alpha$, thus promoting dimerization and high-affinity binding to specific estrogen-responsive elements (EREs) located within the promoter of target genes [2]. ER $\alpha$ is an important prognostic indicator in breast cancer [3] $\mathrm{ER} \alpha$ signaling promotes the growth of primary breast cancers, but can also antagonize signaling pathways that lead to epithelial-mesenchymal transition (EMT) [1, 2, 4-7]. ER $\alpha$-positive breast cancer cells appear to contain a relatively small subpopulation of breast cancer stem cells $[8,9]$. Post-EMT breast cancer cells express cancer stem cell markers, including Bmi1, but show decreased ER $\alpha$ expression $[10,11]$. However, the mechanisms by which $\mathrm{ER} \alpha$ regulates EMT, as well as inhibits stemness in breast cancer, remain to be explored.

In EMT, epithelial cells lose their polarity and acquire the migratory and invasive properties of mesenchymal cells. Cell-to-cell adhesion is mediated by cadherins such as E-cadherin, which provides a structural support for cell-cell attachment. Thus, a loss 
of E-cadherin expression can cause a loss of polarity of epithelial cells and is considered a fundamental event in EMT $[12,13]$. In addition to its crucial role in the differentiation of many tissues and organs, EMT has also been shown to cause organ fibrosis and promote carcinoma progression through a variety of mechanisms [13]. Recent reports suggest a direct link between EMT and the gain of stem-like properties [12,13]. Induction of EMT not only allows cancer cells to disseminate from the primary tumor, but also promotes their self-renewal capability. In breast cancer, EMT is associated with cancer stem cell properties, including the expression of a stem cellassociated $\mathrm{CD} 44^{\text {high }} / \mathrm{CD} 24^{\text {low }}$ antigenic profile, and selfrenewal capabilities [10]. Despite this, the molecular pathways linking EMT to the acquisition of stem cell properties remain, as yet, largely undefined.

Increasing evidence suggests that the polycomb group of transcription factor proteins plays a crucial role in cancer development and recurrence. Of these, Bmil is a member of the polycomb-repressive complex 1, which is strongly involved in the self-renewal of stem cells and is associated with a number of human malignancies such as oropharyngeal cancer, neuroblastoma and melanoma [14-18]. Bmil maintains the self-renewal of both normal and malignant human mammary stem cells [19], suppresses E-cadherin, and enhances stemness in head and neck cancer cells [20]. Bmil also plays an important role in both EMT and stemness processes in human nasopharyngeal and pancreatic cancers [21, 22]. In a previous study, ER $\alpha$ was demonstrated to up-regulate the expression of E-cadherin both directly and indirectly $[2,7,23,24]$. However, whether EMT inhibition by ER $\alpha$ is mediated through a direct/indirect upregulation of E-cadherin remains poorly understood, and further, the regulatory mechanism of Bmil in cancer cells and its role in metastasis are largely unknown.

We hypothesized that $\operatorname{ER} \alpha$ may upregulate E-cadherin through a Bmil-mediated pathway. We investigated this process in vitro in breast cancer cells, and in vivo in a mouse model and human breast cancer tissues.

\section{RESULTS}

\section{Estrogen hormone (E2) and ER $\alpha$ downregulates Bmil expression and increases E-cadherin expression in breast cancer cells}

As was previously reported, post-EMT breast cancer cells express cancer stem cell markers, including Bmi1, but display decreased ER $\alpha$ expression [1]. In order to quantify Bmil expression in breast cancer cells, we detected Bmil protein expression by Western blot in various breast cancer cell lines. We found that Bmil expression was higher in three ER $\alpha$-negative breast cancer cell lines (SKBR3, BT549, and MDA-MB-231) than in ER $\alpha$-positive T47D or BT474 cells (Figure 1A). To compare Bmi1
mRNA expression in these lines, real-time RT-PCR was performed, with $\beta$-actin used as an internal control. Consistent with Bmil protein expression, Bmil mRNA levels were 2 to 3 fold higher in ER $\alpha$-negative breast cancer cell lines than in in ER $\alpha$-positive cells (Figure 1B).

Because both protein and mRNA levels of Bmil were decreased in ER $\alpha$-positive T47D cells relative to ER $\alpha$-negative breast cancer cell lines, we determined whether ER $\alpha$ signaling played a role in Bmil expression. T47D cells cultured in estrogen-depleted medium were treated with various concentrations of E2. After 24 or $72 \mathrm{~h}$, Bmil protein and mRNA levels were dose-dependently downregulated by E2 (Supplemental Figures 1A, 1B; Figures $1 \mathrm{C}, 1 \mathrm{D}$, respectively). When the cells were treated with E2 at $10^{-7} \mathrm{M}$ for $72 \mathrm{~h}$, Bmil mRNA levels were significantly reduced by approximately $70 \%$ (Figure 1D; $P<0.05)$, and protein levels were decreased by more than 90\% (Figure 1C).

To further investigate the impact of $\mathrm{ER} \alpha$ on Bmi1, we silenced endogenous ER $\alpha$ in T47D cells using siRNA and examined Bmil and E-cadherin expression. As shown in Figures $1 \mathrm{E}$ and $1 \mathrm{~F}$, silencing endogenous ER $\alpha$ in T47D cells led to the significant up-regulation of Bmil and significant down-regulation of E-cadherin at both protein and mRNA levels $(P<0.05)$, respectively, in a dosedependent manner.

To investigate the effect of ER $\alpha$ on Bmil expression in an ER $\alpha$-negative breast cancer cell line, we stably transfected the recombinant vector $\mathrm{pEGFP-C1-ER} \alpha$, or an empty vector, into ER $\alpha$-negative BT549 cells. ER $\alpha$ protein and mRNA levels $(P<0.05)$ were increased in pEGFPC1-ER $\alpha$-, but not control, vector-transfected BT549 cells (Figures $1 \mathrm{G}$ and $1 \mathrm{H}$, respectively). We further analyzed the expression of Bmil and E-cadherin. Bmil was markedly downregulated and E-cadherin was upregulated at both the protein level, and significantly, at the mRNA level in pEGFP-C1-ER $\alpha$, as compared with pEGFP-C1 transfected BT549 cells (Figures 1G, 1H; $P<0.05$ for mRNA).

\section{ER $\alpha$ down-regulates Bmi1 expression by directly binding to the $B M I 1$ promoter}

Based on our previous findings that Bmil expression is transcriptionally regulated by ER $\alpha$ signaling, we addressed whether ER $\alpha$ can directly bind to the regulatory regions of the $B M I 1$ promoter. To determine the binding site, we searched for specific EREs located within the BMII promoter. We did not find classical ERE sites but instead found a half-ERE site at position -178 to -174 (Figure $2 \mathrm{~A}$ ). To investigate whether $\mathrm{ER} \alpha$ could form a complex with the BMI1 promoter, we performed a chromatin immunoprecipitation (ChIP) assay with primers covering the $B M I 1$ promoter region. We used a far upstream region, beyond the half-ERE site, in the $B M I 1$ promoter as a negative control. ER $\alpha$ bound to the region between positions -237 to -106 containing the half-ERE 
A

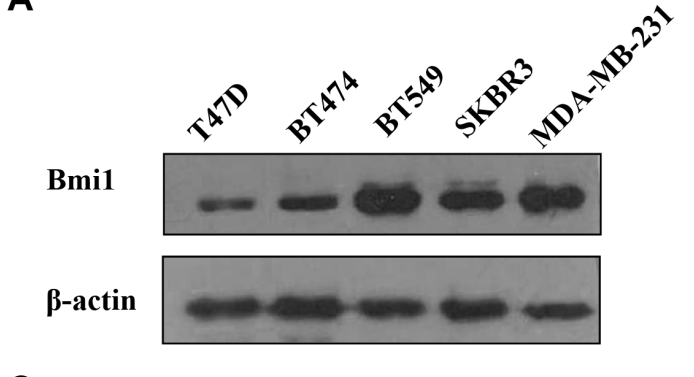

C
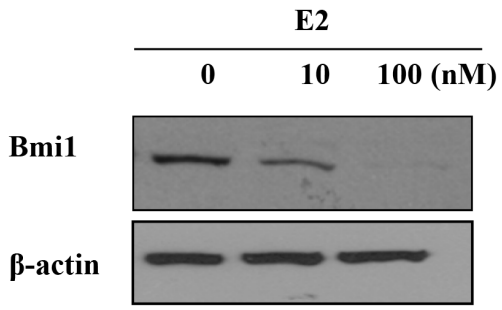

E

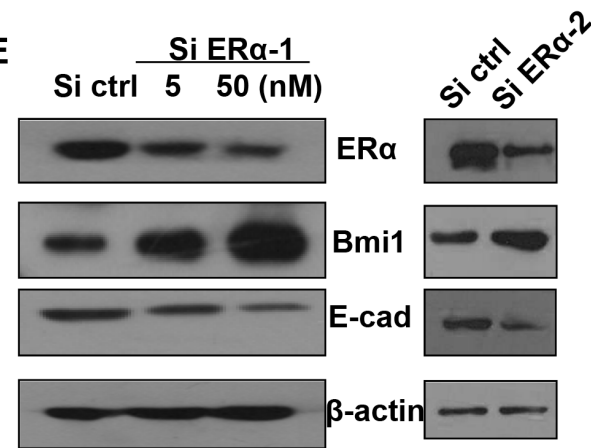

G

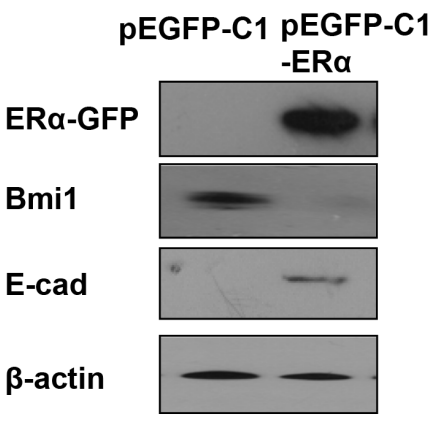

H
B
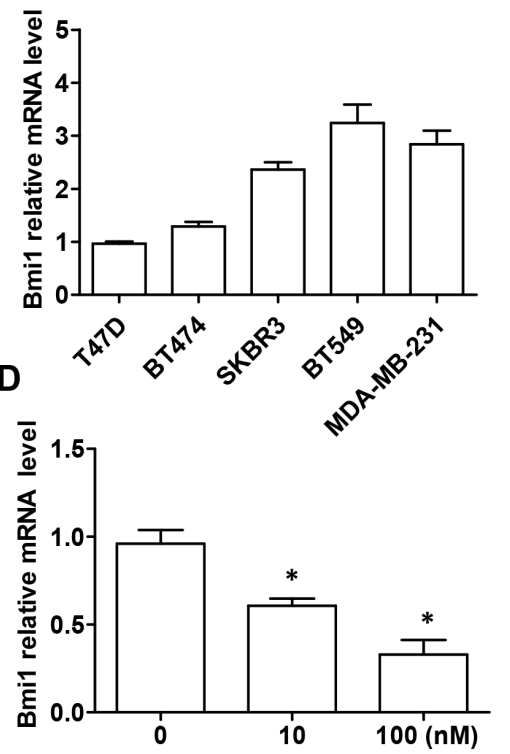

$\mathbf{F}$
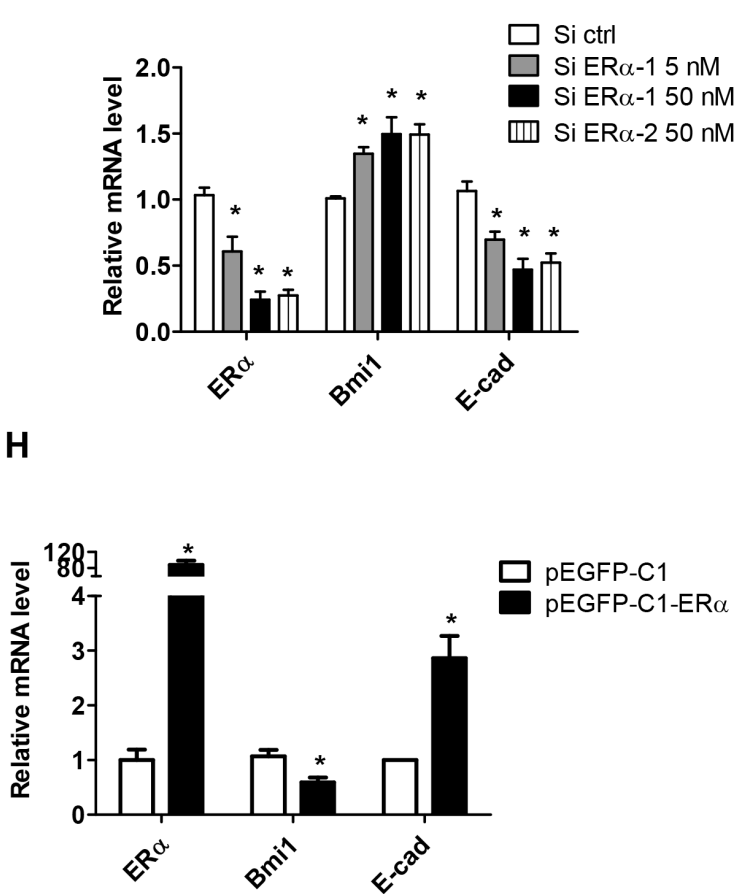

Figure 1: E2 and ERa downregulates Bmi1 expression and increases E-cadherin expression in breast cancer cells. A-B. Western blot (A) and quantitative real-time RT-PCR analysis (B) of protein and mRNA expression of Bmil in ER $\alpha$-positive T47D and BT474 cells, and ER $\alpha$-negative breast cancer cells (SKBR3, BT549 and MDA-MB-231). C-D. T47D cells were maintained in phenol redfree DMEM with $10 \%$ dextran-coated charcoal-treated FBS for $48 \mathrm{~h}$, and cells then treated with either ethanol vehicle or E2 (10 or $100 \mathrm{nM})$ for $72 \mathrm{~h}$. Cells were harvested and analyzed for Bmil mRNA and protein levels. Data are mean $\pm \operatorname{SEM}(n=3) . * P<0.05$ compared with ethanol vehicle (Student's $t$ test). E-F. Western blot (E) and quantitative RT-PCR analysis (F) of protein and mRNA levels in T47D cells transfected with control siRNA, ER $\alpha$ siRNA-1 (5 and $50 \mathrm{nM})$ or ER $\alpha$ siRNA-2 $(50 \mathrm{nM})$. G-H. ER $\alpha$, Bmil and E-cadherin protein and mRNA levels in BT549 cells stably transfected with the indicated vectors. Protein expression was normalized to $\beta$-actin mRNA. ${ }^{*} P<0.05$ compared with control cells (Student's $t$ test).

site, but not the region between positions -1184 to -1023 , which did not contain the ERE/half-ERE binding site (Figure 2B).
Electrophoretic mobility shift assay (EMSA) revealed an ER $\alpha$-binding band after the incubation of nuclear extracts from BT549 cells overexpressing ER $\alpha$ 
A

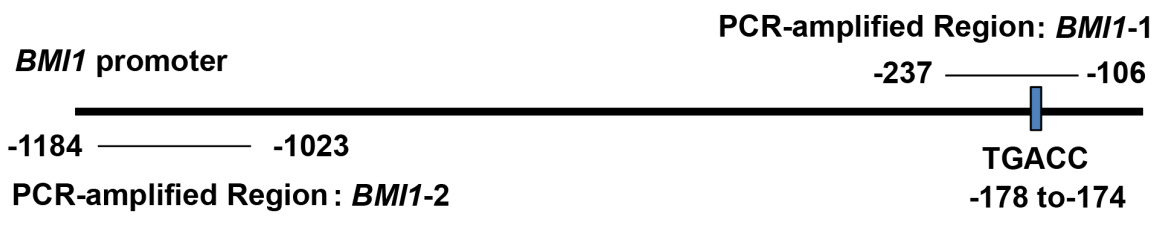

B

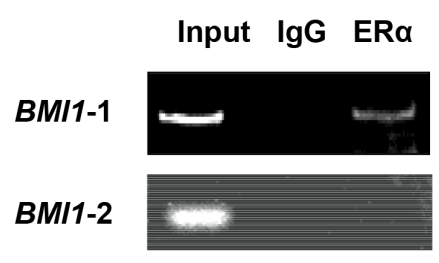

D
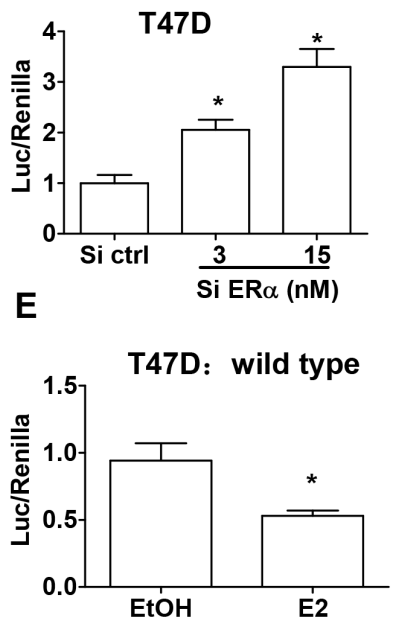

G

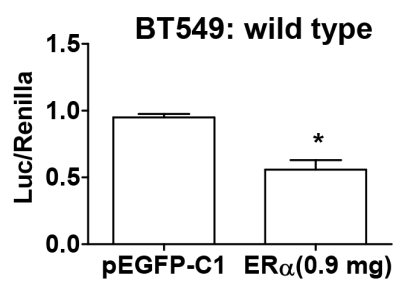

C

$\begin{array}{lllllllll}\text { Labeled probe } & + & + & + & + & + & + & + & + \\ \text { Cell nuclear extract } & + & + & + & + & + & + & + & + \\ \text { Unlabeled probe } & + & - & - & - & - & - & - & - \\ \text { Mutant probe } & - & - & + & - & - & - & - & - \\ \text { Poly (dl-dC) } 25 \mathrm{ng} & - & - & - & + & - & - & - & - \\ \text { Poly (dl-dC) } 125 \mathrm{ng} & - & - & - & - & + & - & - & - \\ \text { Unrelated Ab lgG } & - & - & - & - & - & + & - & - \\ \text { Unrelated Ab Twist1 } & - & - & - & - & - & - & + & - \\ \text { Anti-ERa Ab } & - & - & - & - & - & - & - & +\end{array}$

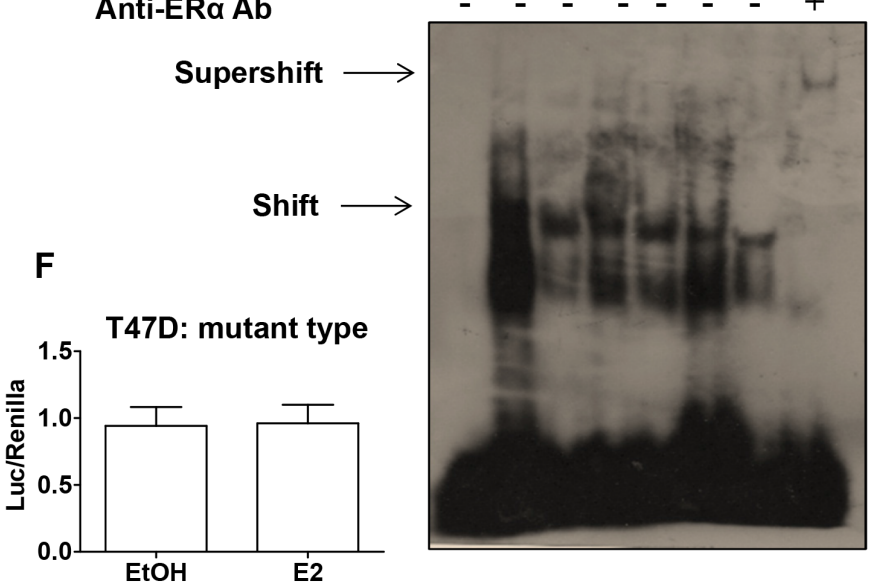

H

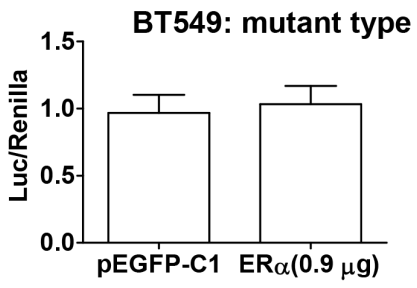

Figure 2: Bmi1 expression is directly regulated by ERa. A. A schematic representation of the $B M I 1$ promoter region, with or without the half-ERE site for ER $\alpha$. Precipitated DNA was amplified by PCR with specific primers for regions 1-2. B. Chromatin immunoprecipitation (ChIP) assay involved normal $\operatorname{IgG}(\operatorname{IgG})$, or anti-ER $\alpha(\operatorname{ER} \alpha)$ antibody to identify the ER $\alpha$ binding site on the $B M I 1$ promoter in T47D cells. C. Electrophoretic mobility shift assay (EMSA). Nuclear extracts from pEGFP-C1-ER $\alpha$-transfected BT549 cells were incubated with a probe labeled at its 3'-end with biotin from the BMII promoter region containing the ER $\alpha$ binding site (lanes 1-8). Unlabeled probe (lane 1) or mutant oligonucleotides (lane 3) were added at 50-fold greater concentrations than that of the labeled probe. In the non-specific binding assay, 25 or $125 \mathrm{ng}$ of poly (dI: $\mathrm{dC}$ ) (lanes 4-5), normal IgG (lane 6), or anti-Twist1 antibody (lane 7) was added. For the supershift assay, the addition of anti-ER $\alpha$ antibody resulted in a supershifted band (lane 8). D. T47D cells were co-transfected with a $B M I 1$ promoter construct (pXP2-BMI1-Luc1000) and ER $\alpha$ siRNA (3 or $15 \mathrm{nM}$ ). E. T47D cells were transfected with a BMI1 promoter construct (pXP2-BMI1-Luc1000) and treated with either ethanol vehicle (EtOH) or $100 \mathrm{nM} \mathrm{E2} \mathrm{(E2)} \mathrm{for} 24 \mathrm{~h}$. F. T47D cells were transfected with pXP2-BMI1-mutant and treated with either ethanol vehicle (EtOH) or $100 \mathrm{nM} \mathrm{E2} \mathrm{(E2)} \mathrm{for} 24 \mathrm{~h}$. G. BT549 cells were co-transfected with pXP2-BMI1-Luc1000 and either pEGFP-C1 or pEGFP-C1-ER $\alpha$. H. BT549 cells were co-transfected with pXP2-BMI1-mutant and either pEGFP-C1 or pEGFP-C1-ER $\alpha$. E-H, All cells were co-transfected with Renilla luciferase plasmid. Luciferase activity was normalized to that of Renilla. ${ }^{*} P<0.05$ (Student's $t$ test) compared with control cells. Data are mean $\pm \operatorname{SEM}(n=3)$. 
with labeled oligonucleotides containing the half-ERE from the $B M I 1$ regulatory region; a supershifted band was seen after the addition of an anti-ER $\alpha$-specific antibody to the mixture (Figure 2C). The addition of excess amounts of unlabeled oligonucleotides containing the half-ERE outcompeted and abolished the binding activity of ER $\alpha$, but not the addition of mutant half-ERE-containing unlabeled oligonucleotides or non-specific competition by poly ( $\mathrm{dI}: \mathrm{dC})$. No supershifted band was seen after the addition of an unrelated antibody, normal $\mathrm{IgG}$, or antiTwist1 antibody, which binds to the E box of the BMII promoter.

To determine the direct regulation of BMI1 by $\mathrm{ER} \alpha$, we used a luciferase reporter vector that included the region from -1000 to -1 of the BMI1 gene. A dual luciferase reporter assay was used to investigate $B M I 1$ promoter activity in ER $\alpha$-silenced T47D cells or ER $\alpha$ overexpressing BT549 cells by co-transfection with the BMI1 promoter and Renilla luciferase reporter genes. Transfection with ER $\alpha$ siRNA significantly increased BMI1 promoter activity 2 - to 3.5 -fold in T47D cells in a dose-dependent manner (Figure 2D; $P<0.05$ ). E2 administration decreased wild-type $B M I 1$ promoter activity to 0.5 -fold (Figure $2 \mathrm{E} ; P<0.05$ ) but did not show any effect on the mutant BMI1 promoter (Figure 2F). Similarly, ectopic ER $\alpha$ overexpression significantly decreased BMI1 promoter activity to 0.5 -fold in BT549 cells (Figure 2G; $P<0.05$ ), but showed no effect on mutant BMI1 promoter activity (Figure 2H). These results demonstrated that $\mathrm{ER} \alpha$ directly repressed $B M I 1$ transcription by specifically binding to the promoter region of the $B M I 1$ gene.

\section{ER $\alpha$ suppresses EMT and stemness in breast cancer cells}

We next examined BT549 cells, stably transfected with either pEGFP-C1 or pEGFP-C1-ER $\alpha$ vector, for morphological changes indicating EMT (Figure 3A). pEGFP-C1 BT549 cells possessed a fibroblast-like morphology and displayed pronounced cellular scattering, while pEGFP-C1-ER $\alpha$ BT549 cells expressing ER $\alpha$ showed a morphological conversion from a spindleshaped, mesenchymal morphology to a cuboidal, epithelial morphology (Figure 3A). Through seeding small amounts of cells, apparent morphological change could be seen after $48 \mathrm{~h}$ culture (Supplemental Figure 2). In contrast, silencing endogenous ER $\alpha$ expression in T47D cells resulted in a partial loss of epithelial characteristics (Figure 3B).

To further investigate the impact of ER $\alpha$ on EMT, we determined migratory and invasive behaviors in $\mathrm{ER} \alpha$ stably-transfected BT549 cells. The healing of wounded areas was significantly slower by about $65 \%$ in pEGFP-C1-ER $\alpha$, compared to pEGFP-C1, BT549 cells (Figure 3C; $P<0.05$ ). Overexpression of ER $\alpha$ in BT549 cells significantly decreased the level of migration to about $50 \%$ of the control (Figure 3D; $P<0.05$ ). Matrigel invasion chamber assays revealed that overexpression of ER $\alpha$ markedly reduced, to about $35 \%$ of capacity, the invasiveness of BT549 cells (Figure 3E: $P<0.05$ ).

Post-EMT mammary epithelial cells show an increased capability of mammosphere formation and an increased CD44 $4^{\text {high}} / \mathrm{CD} 24^{\text {low }}$ cell population, both of which are characteristics of normal mammary and breast cancer stem cells [14-16]. The mammosphere formation assay showed a significant decrease in both the size and number of mammospheres in pEGFP-C1-ER $\alpha$ BT549 cells (Figure 3F; $P<0.05$ and Supplemental Figure 3). To determine whether ER $\alpha$ expression decreased the cancer stem cell-like cell population by suppressing EMT, we analyzed the CD $44^{\text {high }} / \mathrm{CD} 24^{\text {low }}$ cell population in ER $\alpha$ stably-transfected BT549 cells. Most of the control pEGFP-C1 BT549 cells showed a CD44 high/ CD24 $4^{\text {low }}$ phenotype, which was significantly decreased, from $76 \%$ to $7 \%$ of the cell population in pEGFP-C1-ER $\alpha$ BT549 cells (Figure 3G; $P<0.05$ ). These results indicate that ER $\alpha$ suppresses both the expression of cell surface markers and functional characteristics associated with cancer stem cells.

\section{ERo decreased the metastatic ability of BT549 cells in vivo}

To test whether ER $\alpha$ overexpression indeed decreases the metastatic ability of BT549 cells in vivo, a tail vein metastatic model was established in BALB/c nude mice. At 6 weeks following the injection of tumor cells, animals were sacrificed and lung metastasis was examined by H\&E staining. Three of the five mice implanted with BT549 cells developed lung metastases. In contrast, mice implanted with BT549 cells overexpressing ER $\alpha$ showed no evident metastatic nodules in lungs (Figures 4A, 4B). Experimental and control groups did not show metastasis in the liver (data not shown).

\section{Restoration of Bmi1 expression reverses ER $\alpha$-mediated suppression of EMT and stemness}

Next, we investigated the role of Bmil in ER $\alpha$-mediated suppression of EMT and stemness properties in breast cancer cells. A Bmil expression vector or empty vector was transiently transfected into pEGFP-C1-ER $\alpha$ BT549 cells; restoration of Bmil expression resulted in the loss of E-cadherin expression (Figures 5A, 5B), significantly increased migration or invasion (Figures 5C, 5D; $P<0.05$ for both), and significantly increased mammosphere-forming ability (Figure 5E; $P<0.05$ ). Restoration of Bmil expression did not affect the protein level of ER $\alpha$ (Figure 5B), and we therefore conclude that $\mathrm{ER} \alpha$ is an upstream regulator of Bmi1, with no feedback regulation between ER $\alpha$ and Bmil. 
A

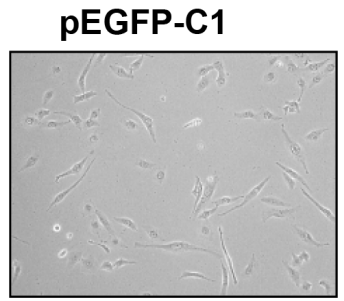

C

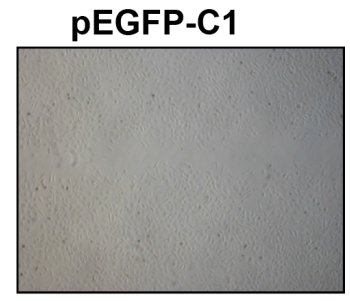

D

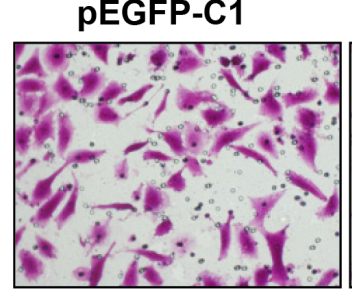

E

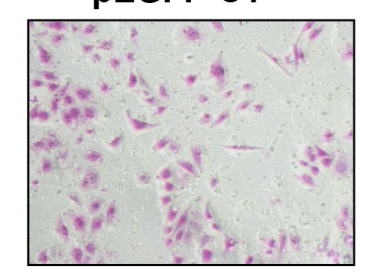

F

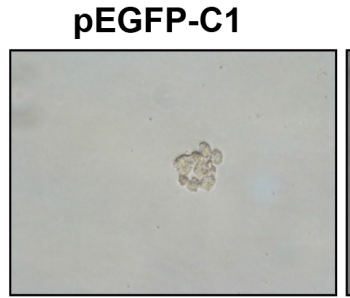

G

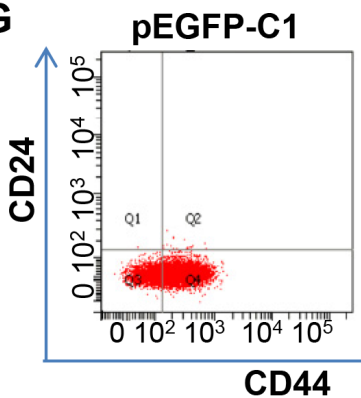

pEGFP-C1-ER $\alpha$

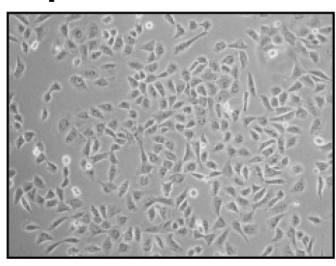

pEGFP-C1-ER $\alpha$

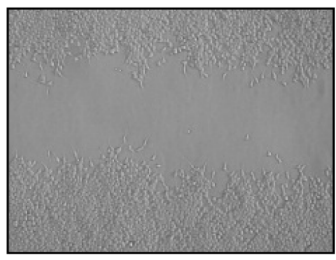

pEGFP-C1-ER $\alpha$

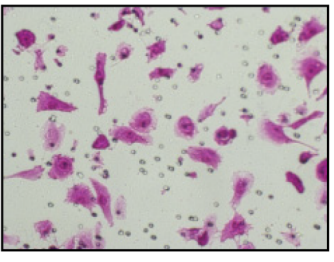

pEGFP-C1-ER $\alpha$

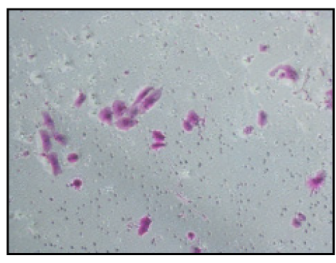

pEGFP-C1-ER $\alpha$

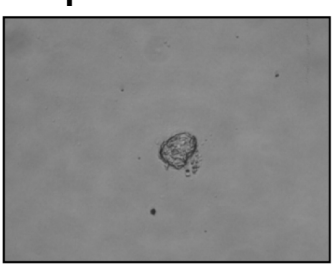

pEGFP-C1-ERa

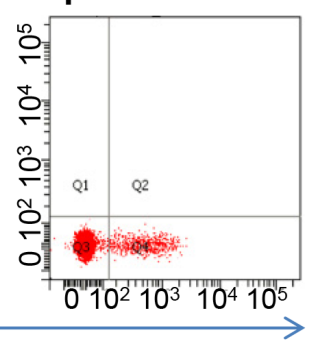

B Si ctrl

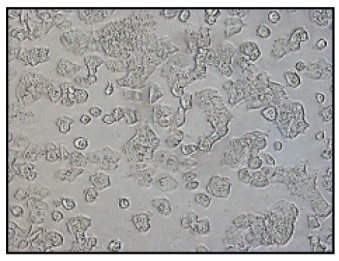

Si ERa
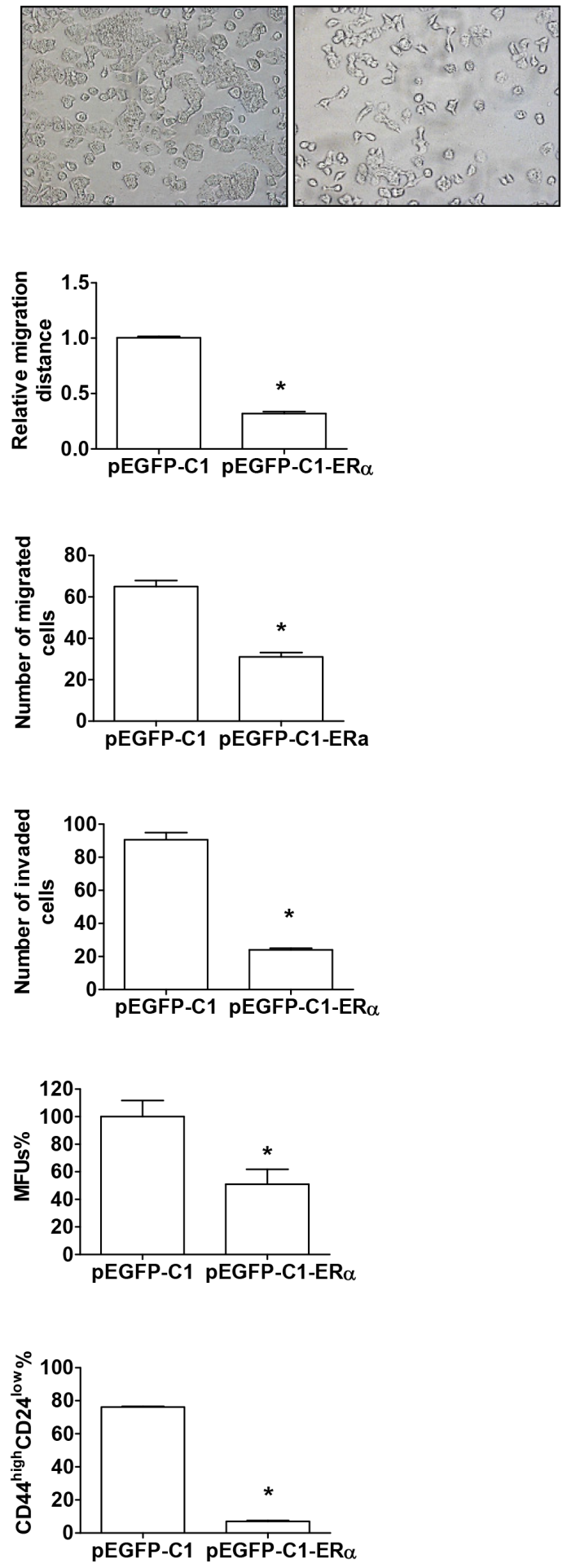

Figure 3: ER $\alpha$ suppresses EMT and cell stemness. A. Morphology of pEGFP-C1 and pEGFP-C1-ER $\alpha$ BT549 cells. B. Morphology of T47D cells transfected with control or ER $\alpha$ siRNA. C. Wound healing assay in pEGFP-C1 or pEGFP-C1-ER $\alpha$ BT549 cells. D-E. Migration and invasion assays of pEGFP-C1 and pEGFP-C1-ER $\alpha$ BT549 cells. Representative images of migrating (D) or invading (E) cells are shown. F. Representative images of mammosphere forming units (MFUs) observed in pEGFP-C1 and pEGFP-C1-ER $\alpha$ BT549 cells. Data are mean \pm SEM $(n=3)$. G. FACS analysis of cell-surface markers CD44 and CD24 in pEGFP-C1 and pEGFP-C1-ER $\alpha$ BT549 cells. Data are mean \pm SEM $(n=3) . * P<0.05$ compared to pEGFP-C1 BT549 cells (Student's $t$ test). Magnification, $400 \times(\mathrm{A}-\mathrm{B}$, $\mathrm{D}-\mathrm{F}) ; 100 \times(\mathrm{C})$. 
A
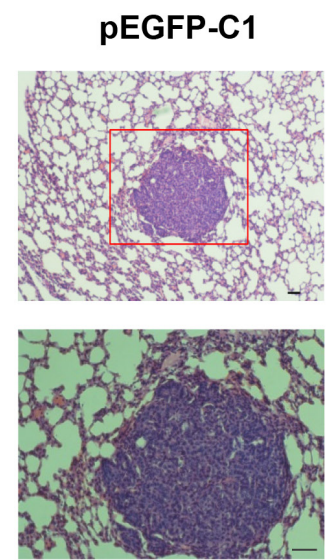

pEGFP-C1-ERa
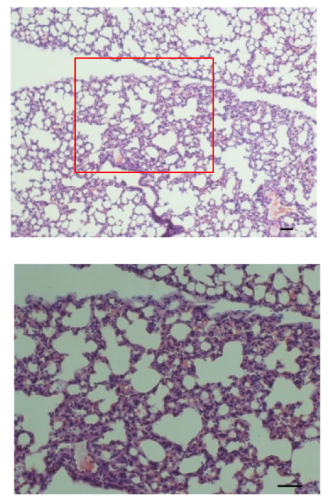

B

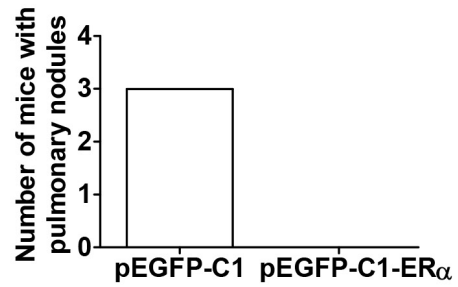

Figure 4: ER $\alpha$ expression reduces the metastasis of BT549 cells. A. H\&E staining of metastatic nodules (red box) in mouse lung tissue. Magnification, $100 \times$ (upper); $200 \times$ (bottom). Bar $=50 \mu$ M. B. Number of mice with pulmonary nodules $(n=5)$.

A
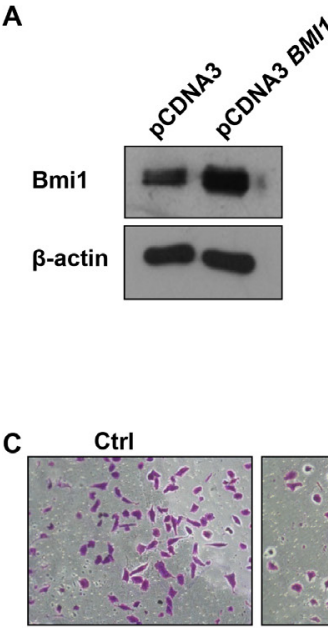

D

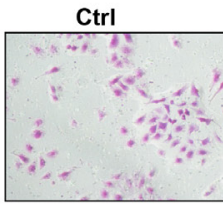

E

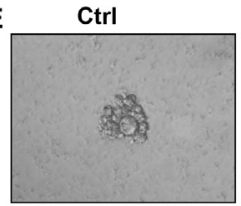

B

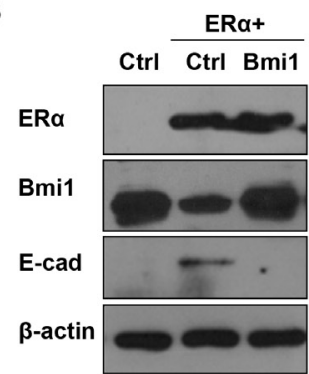

ER $\alpha+C$ trl

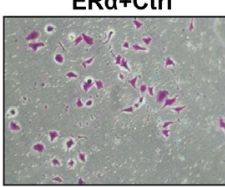

ERa+Ctrl

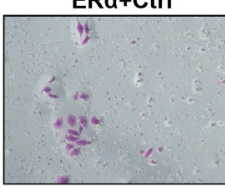

$\mathrm{ER} \alpha+\mathrm{Ctrl}$

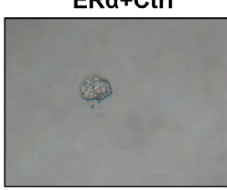

ER $\alpha+B m i 1$
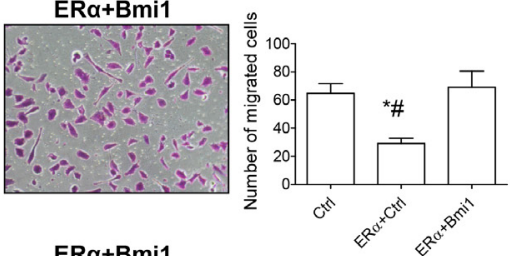

$\mathrm{ER} \alpha+\mathrm{Bmi1}$
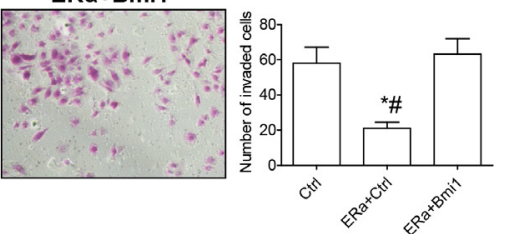

$\mathrm{ER} \alpha+\mathrm{Bmi1}$
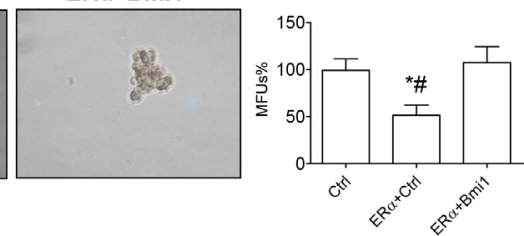

Figure 5: Restoration of Bmil expression reverts ERa-suppressed EMT and stemness. A. Western blot analysis of Bmi1 protein in BT549 cells transfected with the indicated vectors. B. Western blot analysis of ER $\alpha$, Bmil and E-cadherin protein levels in pEGFP-C1 or pEGFP-C1-ER $\alpha$ BT549 cells transiently transfected with the indicated vectors. C-D. Migration and invasion assays. Representative images of migrating (C) or invading cells (D) are shown. E. Morphology and quantification of mammospheres. Ctrl: pEGFP-C1 BT549 cells transiently transfected with control plasmid pcDNA3; ER $\alpha+$ Ctrl: pEGFP-C1-ER $\alpha$ BT549 cells transiently transfected with pcDNA3; ER $\alpha+$ Bmi1: pEGFP-C1-ER $\alpha$ BT549 cells transiently transfected with pcDNA3-BMI1. ${ }^{*} P<0.05$, pEGFPC1-ER $\alpha$ BT549 cells transfected with pcDNA3 (ER $\alpha+C$ trl) compared with pEGFP-C1 BT549 cells transfected with pcDNA3 (Ctrl). $\# P<0.05$, pEGFP-C1-ER $\alpha$ BT549 cells transfected with pcDNA3 (ER $\alpha+$ Ctrl) compared with pEGFP-C1-ER $\alpha$ BT549 cells transfected with pcDNA3 BMI1 (ER $\alpha+B m i 1)$ (Student's $t$ test). Data are mean $\pm \operatorname{SEM}(n=3)$. Magnification, $400 \times(\mathrm{C}-\mathrm{E})$. 


\section{Bmi1 expression is negatively associated with $\mathrm{ER} \alpha$ and $\mathrm{E}$-cadherin levels in human breast cancer}

We further analyzed the mRNA levels of Bmil and E-cadherin in 58 human breast cancer samples. Bmil mRNA levels were significantly lower in ER $\alpha$-positive than in ER $\alpha$-negative tissues (Figure 6A; $P<0.05$ ), but E-cadherin mRNA levels were significantly higher in $\mathrm{ER} \alpha$-positive than in ER $\alpha$-negative tissues (Figure 6B; $P<0.05$ ). Furthermore, immunohistochemistry staining for Bmi1, ER $\alpha$ and E-cadherin revealed that Bmil expression was inversely associated with $\mathrm{ER} \alpha$ and E-cadherin levels in human breast cancer specimens in a significant manner (Table 1 and Figure 6C; $P<0.05$ ). We demonstrated an inverse linear correlation of $E R \alpha$ or E-cadherin expression, with Bmil expression, when the percentage of positively stained cells for each protein was determined in human breast cancer tissues (Figures 6D and $6 \mathrm{E} ; P<0.05$ ). These results support a model of $\mathrm{ER} \alpha$ interacting with the Bmil locus, leading to the transcriptional repression of Bmil for the downregulation of E-cadherin.

\section{DISCUSSION}

Breast cancer is the most commonly diagnosed cancer in women and remains one of the leading causes of death [1]. Most breast cancer-related deaths occur after extensive metastasis, during which EMT endows cancer cells with increased migration and invasive capabilities. Since ER $\alpha$ has been shown to suppress EMT, efforts to elucidate the molecular mechanisms by which ER $\alpha$ regulates EMT, as well as inhibits stemness, in breast cancer are warranted in order to develop novel treatments for this common type of cancer. In the current study, we have demonstrated that ER $\alpha$ can suppress Bmil expression by transcriptional repression, and inhibit EMT and stemness in breast cancer through an ER $\alpha$-Bmil-E-cadherin pathway.

The loss of E-cadherin expression is considered to be a fundamental event in EMT [13]. Several mechanisms, including transcriptional repression and methylation of the promoter, have been shown to repress E-cadherin expression. Many transcription factors, such as Snail, Slug and Zeb1, can bind to the E-cadherin promoter and directly repress its transcription [25-28], whereas other factors, such as Twist1 and FoxC2, can repress E-cadherin indirectly. This results in a disrupted polarity of epithelial cells and induced EMT [29, 30], thus maintaining the mesenchymal phenotype and enhancing the invasiveness and metastasis of cancer cells [31].

Bmil can downregulate E-cadherin expression and induce EMT in head and neck cancer by directly binding to E-box consensus sequences in the promoter region of E-cadherin [20]. Bmil can also indirectly repress E-cadherin expression by activating Snail in breast [32] and nasopharyngeal cancer [21]. In breast cancer, Bmil and E-cadherin levels were inversely related, while Bmil expression inversely correlated with the prognosis [32]. Although numerous studies have demonstrated that the regulation of E-cadherin can be mediated by ER $\alpha$, and that the loss of E-cadherin was regulated by Bmi1, no studies have outlined the involvement of Bmil in an ER $\alpha$ mediated E-cadherin regulation and EMT transition.

The presence of $E R \alpha$ represents a epithelial phenotype in the breast. Previous studies suggested that $\mathrm{ER} \alpha$ upregulates several epithelial markers, such as E-cadherin, in breast cancer cells. In studying the role of Bmil in hormone-dependent and -independent breast cancer cells, we found that Bmil mRNA and protein levels were lower in ER $\alpha$-positive than in ER $\alpha$-negative cells. Furthermore, estrogen stimulation downregulated Bmil expression in hormone-dependent breast cancer cells, while in hormone-independent cells, Bmil was downregulated by ER $\alpha$ overexpression. When ER $\alpha$ expression was silenced by RNA interference, Bmi1 became upregulated. These findings suggest that ER $\alpha$ modulates the Bmil signaling pathway.

$E R \alpha$ has previously been shown to bind to the ERE/half-ERE region in the promoter of its downstream genes to regulate gene expression [33, 34]. For instance, ER $\alpha$ can repress Slug transcription by binding to the half-ERE element in the Slug promoter to regulate

Table 1: Association of Bmi1, ER $\alpha$ and E-cadherin expression in human breast cancer tissues

\begin{tabular}{|c|c|c|c|c|}
\hline & \multirow{2}{*}{$n$} & \multicolumn{2}{|c|}{ Bmi1 } & \multirow{2}{*}{$P$ value } \\
\hline & & Negative $(\%)$ & Positive (\%) & \\
\hline \multicolumn{5}{|l|}{ ER $\alpha$} \\
\hline Negative & 26 & $13(50.0)$ & $13(50.0)$ & 0.003 \\
\hline Positive & 32 & $28(87.5)$ & $4(12.5)$ & \\
\hline \multicolumn{5}{|l|}{ E-cadherin } \\
\hline Negative & 28 & $16(57.1)$ & $12(42.9)$ & 0.043 \\
\hline Positive & 30 & $25(83.3)$ & $5(16.7)$ & \\
\hline
\end{tabular}


A

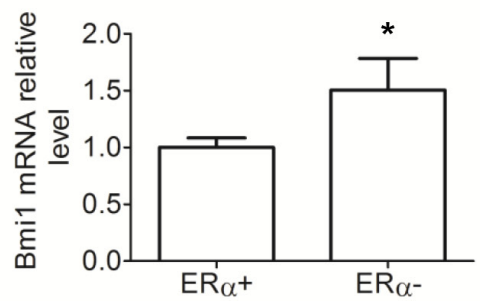

C
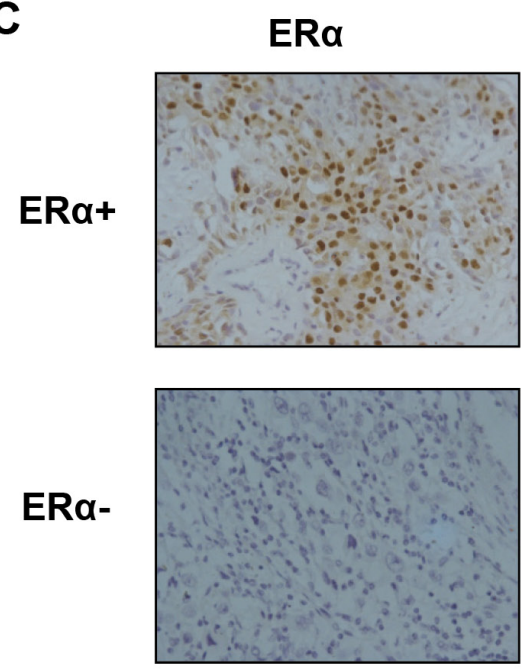

D

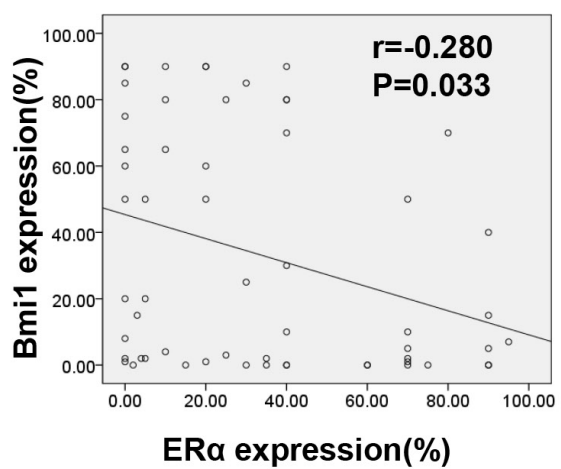

B

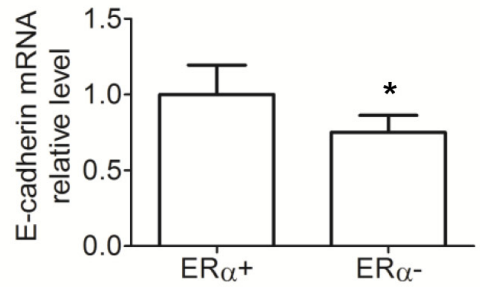

Bmi1
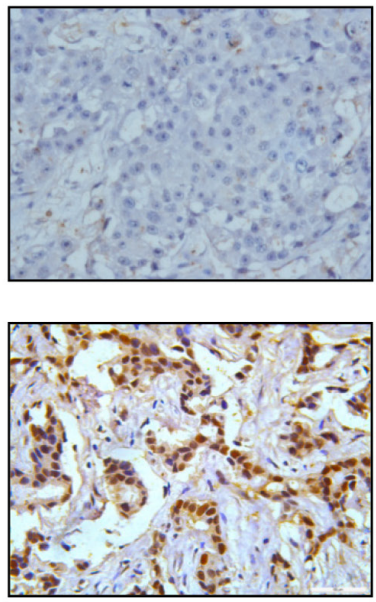

E-cadherin
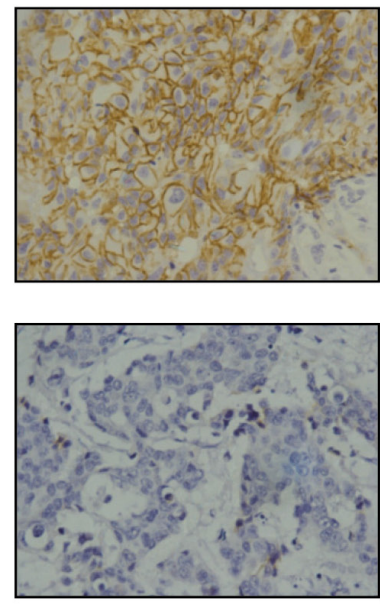

E

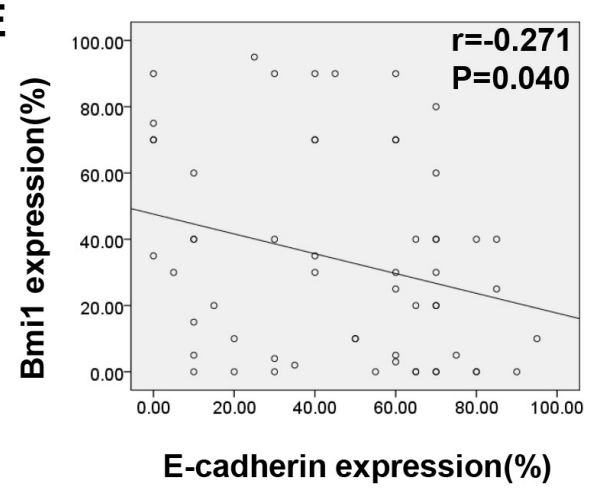

Figure 6: Association of Bmi1 and E-cadherin expression in 58 human breast cancer tissues. A, B. Relative mRNA levels of Bmil (A) and E-cadherin (B) with ER $\alpha$-negative and ER $\alpha$-positive expression in breast cancer tissues. ${ }^{*} P<0.05$ (Student's $t$ test). C. Representative fields of positive ER $\alpha$, negative Bmil and positive E-cadherin (upper row) and negative ER $\alpha$, positive Bmil, and negative E-cadherin (lower row). Magnification, 400× (C) D. Scatter plot of Bmil and ER $\alpha$ positive, immunohistochemically stained percentages of cells in human breast cancer tissues. E. Scatter plot of Bmil and E-cadherin positive, immunohistochemically stained percentages of cells in human breast cancer tissues (Spearman's Rank Correlation Test).

E-cadherin expression and EMT [2, 7]. Interestingly, the $B M I 1$ promoter sequence includes a half-site ERE element (TGACC). Evidence that ER $\alpha$ directly binds to the TGACC site in the BMI1 promoter suggests that ER $\alpha$ mediated Bmil suppression is indeed regulated at the transcriptional level. This conclusion is further supported by our dual luciferase reporter gene assay revealing increased/decreased activity of a BMII promoter-driven reporter gene in ER $\alpha$ silenced/overexpressing breast cancer cells. Our findings indicate that ER $\alpha$ suppresses Bmil expression by directly binding to the half-ERE site of the BMI1 promoter, thereby demonstrating a novel pathway by which ER $\alpha$ suppresses migration, invasion, and EMT in breast cancer cells, in addition to modulating Slug $[2,7]$ and NF-kB [6] pathways. Interestingly, a recent article by Wang et al. reported that ER $\alpha$ bound 
to the promoter of Bmi1, as also identified by our study, suggesting that the ER $\alpha$ could transcriptionally modulate Bmil expression [35]. In contrast to our findings, however, Wang's study found that Bmil expression was upregulated by the overexpression of ER $\alpha$ in another ER $\alpha$ positive breast cancer cell line, MCF-7, while depletion of this protein caused a down-regulation of Bmil. Whether this well-demonstrated, opposing regulation is cell linespecific needs to be investigated in future studies.

Song et al. showed that Bmil could inhibit phosphatase and tensin homologs, induce EMT and also regulate the self-renewal and differentiation of stem cells in human nasopharyngeal epithelial cells [21]. In pancreatic cancer, the EMT-activator, Zeb1, maintains stemness of cells, in part, through Bmi1 [22]. In our study, the elevated expression of ER $\alpha$ decreased the CD44 high/ CD24 $4^{\text {low }}$ cell population in breast cancer cells and inhibited the cells' capacity to form mammospheres. Most importantly, restoring Bmil expression reversed the ER $\alpha$ mediated suppression of EMT and stemness. The current findings highlight the critical role of Bmil in regulating both EMT and stemness in breast cancer cells. Although $\mathrm{ER} \alpha$ expression represses the stemness of cancer cells, the underlying mechanism of ER $\alpha$ in regulating stemness has not been thoroughly explored. $\mathrm{ER} \alpha$ may modulate the stemness of breast cancer cells by suppressing Bmil expression, and may therefore be considered an inhibitor of circulating and migrating cancer stem cells.

In summary, our results demonstrate that $\mathrm{ER} \alpha$ can suppress EMT in human breast cancer cells through the transcriptional down-regulation of Bmil and its downstream genes. An inverse relationship between ER $\alpha$ and Bmil expression further supports the epithelial phenotype of ER $\alpha$-positive tumors, or the mesenchymal phenotype of ER $\alpha$-negative tumors, as being most likely regulated via the ER $\alpha-B m i 1-E$-cadherin axis. Our findings provide a novel mechanistic insight into how ER $\alpha$ regulates EMT and may be of value in developing new biomarkers for the prognosis of breast cancer.

\section{MATERIALS AND METHODS}

\section{Cell lines, antibodies and plasmids}

BT474, T47D, MDA-MB-231, BT549 and SKBR3 breast cancer cell lines were purchased from the Committee on Type Culture Collection of the Chinese Academy of Science (Shanghai, China). The pEGFP-C1-ER $\alpha$ plasmid was purchased from Addgene (Cambridge, MA, USA), and pcDNA3-BMI1 plasmid was a gift from Dr. MH Yang (Institute of Clinical Medicine, National Yang-Ming University, Taipei city, Taiwan) [20]. A wild type BMI1 promoter (pXP2-BMI1-Luc1000) from -1023 to -1 was constructed and a mutant BMI1 promoter was generated by replacing a TGACC $(-178-174)$ sequence in the wild type BMI1 promoter with a GACCC sequence. The following antibodies were used in this study: anti-E-cadherin (DAKO, Glostrup, Denmark; NCH-38), anti-Bmil (Abcam, Cambridge, UK; ab126783), anti-ER $\alpha$ (Santa Cruz Biotechnology, CA, USA; sc-543), anti- $\beta$-actin (Santa Cruz Biotechnology, Dallas, TX, USA; sc-4777), PE-conjugated anti-CD24 (BD Biosciences, Bedford, MA, USA; ML5), APCconjugated anti-CD44 (BD Pharmigen, San Jose, CA, USA; G44-26), PE-conjugated mouse IgG (BD; G155$178)$, and APC-conjugated mouse IgG (BD; 27-35).

\section{Transfections}

We transfected $5 \mu \mathrm{g}$ of the vectors, pEGFP-C1 or pEGFP-C1-ER $\alpha$, containing full-length human ER $\alpha$, into BT549 cells growing in 10-cm tissue culture plates using Lipofectamine 2000 (Invitrogen, Carlsbad, CA, USA). Stable clones were selected and established by culturing in Dulbecco's modified Eagle's medium (DMEM) plus 10\% fetal bovine serum (FBS) containing $0.8 \mathrm{mg} / \mathrm{mL} \mathrm{G418}$ (Merck \& Co., Whitehouse Station, NJ, USA). To clarify the role of Bmi1, $5 \mu \mathrm{g}$ of pcDNA3 or pcDNA3-BMI1 was transfected into $\mathrm{pEGFP-C1-ER} \alpha$ stable cells growing in $10-\mathrm{cm}$ tissue culture plates for $48 \mathrm{~h}$. ER $\alpha$ siRNA and scrambled siRNA were synthesized by Genepharma Biotech (Shanghai, China). ER $\alpha$ siRNA-1 sequences were as follows [2]: 5'-CGAGUAUGAUCCUACCAGAII-3' (sense) and 5'-UCUGGUAGGAUCAUACUCGGA-3' (antisense); siRNA-2 sequences: 5'-AAGCUACUGUUUGCUCCUAACTT-3' (sense) and 5'-GUUAGGAGCAAACAGUAGCUUTT-3' (antisense). Scrambled siRNA sequences were 5'-UUCUCCCGAACGUUCACGU-3' (sense) and 5'-ACGUGACACGUUCGGAGAA-3' (antisense). Transfection of siRNA involved the use of Lipofectamine 2000. Briefly, 5 or $50 \mathrm{nmol} / \mathrm{L}$ ER $\alpha$ siRNA or scrambled siRNA was transfected into cultured T47D cells (at 50\% confluence) for $48 \mathrm{~h}$.

\section{RNA isolation and RT-PCR}

TRIzol reagent (Invitrogen, Carlsbad, CA) was used to isolate total RNA from cultured cells or fresh-frozen breast cancer tissue. The PrimeScript RT Reagent Kit (Takara, Dalian, China) with random primers was used to synthesize cDNA. PCR reactions involved $2 \mu \mathrm{L}$ cDNA and the ABI PRISM 7300 Sequence Detection System (Applied Biosystems, Foster City, CA, USA). Expression was normalized to that of the $\beta$-actin housekeeping gene as an internal control. The primer sequences were for $\beta$-actin, 5'-AGCGAGCATCCCCCAAAGTT-3' (sense) and 5'-GGGCACGAAGGCTCATCATT-3' (antisense); $\mathrm{ER} \alpha$, 5'-TGCTTCAGGCTACCATTATGGA-3' (sense) and 5'-TGGCTGGACACATATAGTCGTT-3' (antisense); Bmi1, 5'-GCTGCCAATGGCTCTAATGAA-3' (sense); and 5'-TGCTGGGCATCGTAAGTATCTT-3' (antisense); 
E-cadherin, 5'-AAAGGCCCATTTCCTAAAAACCT-3' (sense) and 5'-TGCGTTCTCTATCCAGAGGCT-3'.

\section{Chromatin immunoprecipitation (ChIP) assay}

ChIP assays were performed as previously described [36]. In brief, T47D cells at $80 \%$ to $90 \%$ confluence growing in $10-\mathrm{cm}$ dishes were treated with $1 \%$ formaldehyde for $10 \mathrm{~min}$ to cross-link proteins to DNA, and then sonicated four times for $10 \mathrm{sec}$ by use of a sonicator with a microtip in a $1.5-\mathrm{mL}$ tube. The resultant lysate underwent immunoprecipitation (IP) with $1 \mu \mathrm{g}$ polyclonal anti-ER $\alpha$ antibody. Normal IgG was used as an IP control, and the supernatant was used as an input control. Immunoprecipitated complexes were collected by adding protein A/Gagarose/salmon sperm DNA beads and incubating samples for $2 \mathrm{~h}$ at $4^{\circ} \mathrm{C}$. The beads were then treated with RNase A $(50 \mu \mathrm{g} / \mathrm{mL})$ and proteinase K. DNA was extracted with phenol/chloroform and co-precipitated with glycogen, dissolved in $25 \mu \mathrm{L}$ TE buffer, and subjected to PCR amplification for ER $\alpha$ binding sites in the BMI1 promoter using specific primers: BMI1-1, 5'-CGGGCCTGACTACACCGACAC-3' (sense), and 5'-GGAAACTGACACCGGCTCCAA-3' (antisense); BMI1-2, GCAGAGGAAAACCAGAAACG-3' (sense) and 5'-TGGGCAGTATCTTTCCCTCTT-3' (antisense). The acquired DNA was resolved on a $2 \%$ agarose gel and stained with Goldview.

\section{Electrophoretic mobility shift assay (EMSA)}

Oligonucleotides

(5'-AGCACGTGACCCGCTGGG-3') containing putative binding sequences of ER $\alpha$ were labeled at the 3 '-end with biotin and incubated with nuclear extracts harvested from BT549 cells transfected with pEGFP-C1-ER $\alpha$. The binding reaction (20 $\mathrm{min}$ at room temperature) was carried out in a final volume of $20 \mu \mathrm{L}$ containing the biotin-labeled probe (20 fmol), with nuclear extract according to the LightShift Chemiluminescent EMSA Kit (Beyotime Biotech, Haimen, China) manufacturer's protocol. In supershift experiments, the nuclear extract was preincubated with anti-ER $\alpha$ antibody for $30 \mathrm{~min}$ on ice. In non-specific binding assays, poly (dI:dC), nonspecific antibodies, including normal IgG or antiTwist 1 antibody, were added instead of anti-ER $\alpha$ antibody. In the competition assay, excess amounts of unlabeled competitors, including putative binding sequences and mutant sequences (5'-AGCACGGACCCCGCTGGG-3'), were added before the labeled probes. After binding, the samples were separated on $6 \%$ non-denaturing polyacrylamide gels and visualized by enhanced chemiluminescence.

\section{Cell migration and invasion assays}

A modified cell migration assay was performed using BT549 cells stably transfected with pEGFP-C1 or pEGFP-C1-ER $\alpha$ cells as described previously [26]. An 8- $\mu$ m pore-size Boyden chamber (BD) was used for in vitro migration and invasion assays. Cells $\left(5 \times 10^{4}\right)$ incubated in DMEM supplemented with $1 \%$ bovine serum albumin were plated in the upper chamber, and $10 \%$ fetal bovine serum was added to DMEM in the lower chamber as a chemoattractant. A BD BioCoat Matrigel Invasion Chamber (BD) was used for the invasion assay. After $24 \mathrm{~h}$ (migration assay) or $72 \mathrm{~h}$ (invasion assay), cells on the upper side of the filter were removed, and cells that remained adherent to the underside of membrane were fixed in $4 \%$ formaldehyde and stained with crystal violet dye. Five random fields per membrane were photographed with the use of a BX51 microscope (Olympus, Tokyo, Japan) at $\times 400$ magnification. The cells were counted and the mean number of the five fields was calculated to obtain a representative number of cells that had migrated/invaded across the membrane. Three independent experiments were performed for each assay.

\section{Wound healing assay}

BT549 cells stably transfected with pEGFP-C1 or pEGFP-C1-ER $\alpha$ were seeded in 6-well plates at a density of $3 \times 10^{5}$ cells/well. Cells were then serum-starved for $24 \mathrm{~h}$, and a linear wound was created in the confluent monolayer by use of a pipette tip. Wound healing was photographed at $24 \mathrm{~h}$ intervals. Experiments were done in triplicate, and three random fields of each well were recorded.

\section{Flow-cytometric analysis of CD44 and CD24 expression}

To analyze CD44 and CD24 expression, cells were trypsinized and suspended in phosphate buffered saline (PBS), plus $1 \%$ fetal bovine serum, at a density of $10^{6}$ cells $/ 100 \mu \mathrm{L}$. Cells were incubated at $4^{\circ} \mathrm{C}$ in the dark for 40 min with PE-conjugated anti-CD44 antibody and APC-conjugated anti-CD24 antibody, or their respective isotype controls, at concentrations recommended by the manufacturer. Labeled cells were washed twice with PBS, then fixed in PBS containing 1\% paraformaldehyde and analyzed with the use of a FACSCalibur flow cytometer (BD).

\section{Mammosphere assay}

Single cells were plated at a density of 1,000 cells $/ \mathrm{mL}$ in 96 -well ultralow attachment plates (Corning, New York, USA). Cells were grown in serum-free DMEM/F12 supplemented with B27 (1:50, Invitrogen), $20 \mathrm{ng} / \mathrm{mL}$ endothelial growth factor, $20 \mathrm{ng} / \mathrm{mL}$ basic fibroblast growth factor and $4 \mu \mathrm{g} / \mathrm{mL}$ heparin (Sigma, St. Louis, MO, USA). Cells were cultured for $7 \mathrm{~d}$, and mammospheres with $>50 \mu \mathrm{m}$ diameter were counted. 


\section{Immunohistochemistry (IHC) of human breast cancer tissues}

Human breast cancer specimens were obtained from 58 patients who underwent breast cancer surgery at the Cancer Hospital of Shantou University Medical College, China between 2010 and 2011. Written informed consent was obtained from each patient, and the study was approved by the Hospital Research Ethics Committee.

Serial formalin-fixed and paraffin-embedded tissues were sectioned at a $4 \mu \mathrm{m}$ thickness, deparaffinized, and rehydrated in gradients of high percentage ethanol to distilled water. For quenching endogenous peroxidase activity, sections were immersed in 3\% hydrogen peroxide for $15 \mathrm{~min}$ at room temperature. Antigen retrieval involved boiling in $10 \mathrm{mM}$ sodium citrate buffer $(\mathrm{pH} 6)$ for $3 \mathrm{~min}$ in a pressure cooker, followed by cooling to room temperature. Sections were then incubated with the primary antibody at $4^{\circ} \mathrm{C}$ overnight, washed three times in PBS for $5 \mathrm{~min}$, and incubated with horseradish peroxidaseconjugated goat anti-mouse/rabbit IgG antibody (ZSGBBio, Beijing, China) at room temperature for $30 \mathrm{~min}$, followed by 3, 3'-diaminobenzidine tetra-hydrochloride (DAB) staining. Sections were lightly counterstained with hematoxylin.

The expression of $\mathrm{ER} \alpha, \mathrm{Bmil}$ and E-cadherin was detected using specific antibodies, with normal mouse or rabbit IgG (Santa Cruz Biotechnology) used as the negative control. Cases were considered as positive for ER $\alpha$ if nuclear immunoreactivity was present in $\geq 10 \%$ of tumor cells. For nuclear Bmil staining, the percentage of stained cells was categorized into 0 to $3+$ as previously described [20]: 0 , no staining; $1+, 1-25 \% ; 2+, 25-50 \%$; and $3+,>50 \%$ nuclear staining. Only $3+$ was considered as a positive IHC result. E-cadherin expression was interpreted as either normal (strong) or aberrant (reduced or absent). Aberrant staining was defined as either negative staining or $<50 \%$ membranous staining of the population of cells examined. Normal staining was defined as $\geq 50 \%$ membranous staining of the cancer cells [37]. The percent of positively stained cells was evaluated, in the same section of tissue, to analyze the correlation between Bmil and ER $\alpha$ or E-cadherin.

\section{In vivo metastasis in mice}

Eight- to 10 -week-old female BALB/C nude mice were intravenously injected, via the tail vein, with $5 \times 10^{7}$ pEGFP-C1 or pEGFP-C1-ER $\alpha$ stable cells in $0.1 \mathrm{~mL}$ PBS (5 mice for each group). Six weeks after injection, mice were euthanized to grossly detect metastases. The visceral organs, such as lung and liver, were fixed with formalin, then paraffin-embedded and stained with hematoxylin and eosin (H\&E). Metastatic lesions were evaluated by microscopic examination. The animal study was approved by the Institutional Animal Care and Use Committee of Shantou University Medical College.

\section{Statistical analysis}

Statistical analysis was performed using SPSS 16.0 (SPSS Inc., Chicago, IL, USA). Differences among variables were assessed by $\chi 2$ analysis, Spearman's Rank Correlation Test or 2-tailed Student's $t$ tests. Data were presented as the mean \pm SEM unless otherwise indicated. Two-sided $P<0.05$ was considered statistically significant. Each experiment was performed at least three times.

\section{ACKNOWLEDGMENTS}

This work is partly supported by the funds from Major State Basic Research Development Program of China (No.2011CB707705), the Natural Science Foundation Committee (No.31271068, 81302331), and the Guangdong Provincial Key Laboratory on Breast Cancer Diagnosis and Treatment Research.

\section{CONFLICTS OF INTERESTS}

None of the authors have any financial or personal relationships with other people or organizations that could inappropriately influence this research.

\section{REFERENCE}

1. Guttilla IK, Adams BD, White BA. ERalpha, microRNAs, and the epithelial-mesenchymal transition in breast cancer. Trends in endocrinology and metabolism: TEM. 2012; 23:73-82.

2. Ye Y, Xiao Y, Wang W, Yearsley K, Gao JX, Barsky SH. ERalpha suppresses slug expression directly by transcriptional repression. The Biochemical journal. 2008; 416:179-187.

3. Parl FF, Schmidt BP, Dupont WD, Wagner RK. Prognostic significance of estrogen receptor status in breast cancer in relation to tumor stage, axillary node metastasis, and histopathologic grading. Cancer. 1984; 54:2237-2242.

4. Shen HM, Tergaonkar V. NFkappaB signaling in carcinogenesis and as a potential molecular target for cancer therapy. Apoptosis : an international journal on programmed cell death. 2009; 14:348-363.

5. Taylor MA, Parvani JG, Schiemann WP. The pathophysiology of epithelial-mesenchymal transition induced by transforming growth factor-beta in normal and malignant mammary epithelial cells. Journal of mammary gland biology and neoplasia. 2010; 15:169-190.

6. Wang X, Belguise K, Kersual N, Kirsch KH, Mineva ND, Galtier F, Chalbos D, Sonenshein GE. Oestrogen signalling inhibits invasive phenotype by repressing RelB and its target BCL2. Nature cell biology. 2007; 9:470-478.

7. Ye Y, Xiao Y, Wang W, Yearsley K, Gao JX, Shetuni B, Barsky SH. ERalpha signaling through slug regulates E-cadherin and EMT. Oncogene. 2010; 29:1451-1462. 
8. Chaffer CL, Brueckmann I, Scheel C, Kaestli AJ, Wiggins PA, Rodrigues LO, Brooks M, Reinhardt F, Su Y, Polyak K, Arendt LM, Kuperwasser C, Bierie B, Weinberg RA. Normal and neoplastic nonstem cells can spontaneously convert to a stem-like state. Proceedings of the National Academy of Sciences of the United States of America. 2011; 108:7950-7955.

9. Peppercorn J, Perou CM, Carey LA. Molecular subtypes in breast cancer evaluation and management: divide and conquer. Cancer investigation. 2008; 26:1-10.

10. May CD, Sphyris N, Evans KW, Werden SJ, Guo W, Mani SA. Epithelial-mesenchymal transition and cancer stem cells: a dangerously dynamic duo in breast cancer progression. Breast cancer research : BCR. 2011; 13:202.

11. Singh A, Settleman J. EMT, cancer stem cells and drug resistance: an emerging axis of evil in the war on cancer. Oncogene. 2010; 29:4741-4751.

12. Raimondi C, Gianni W, Cortesi E, Gazzaniga P. Cancer stem cells and epithelial-mesenchymal transition: revisiting minimal residual disease. Current cancer drug targets. 2010; 10:496-508.

13. Thiery JP, Acloque H, Huang RY, Nieto MA. Epithelialmesenchymal transitions in development and disease. Cell. 2009; 139:871-890.

14. Cao L, Bombard J, Cintron K, Sheedy J, Weetall ML, Davis TW. BMI1 as a novel target for drug discovery in cancer. Journal of cellular biochemistry. 2011; 112:2729-2741.

15. Huber GF, Albinger-Hegyi A, Soltermann A, Roessle M, Graf N, Haerle SK, Holzmann D, Moch H, Hegyi I. Expression patterns of Bmi-1 and p16 significantly correlate with overall, disease-specific, and recurrence-free survival in oropharyngeal squamous cell carcinoma. Cancer. 2011; 117:4659-4670.

16. Park IK, Morrison SJ, Clarke MF. Bmi1, stem cells, and senescence regulation. The Journal of clinical investigation. 2004; 113:175-179.

17. Cui H, Hu B, Li T, Ma J, Alam G, Gunning WT, Ding HF. Bmi-1 is essential for the tumorigenicity of neuroblastoma cells. The American journal of pathology. 2007; 170:1370-1378.

18. Mihic-Probst D, Kuster A, Kilgus S, Bode-Lesniewska B, Ingold-Heppner B, Leung C, Storz M, Seifert B, Marino S, Schraml P, Dummer R, Moch H. Consistent expression of the stem cell renewal factor BMI-1 in primary and metastatic melanoma. International journal of cancer Journal international du cancer. 2007; 121:1764-1770.

19. Liu S, Dontu G, Mantle ID, Patel S, Ahn NS, Jackson KW, Suri P, Wicha MS. Hedgehog signaling and Bmi-1 regulate self-renewal of normal and malignant human mammary stem cells. Cancer research. 2006; 66:6063-6071.

20. Yang MH, Hsu DS, Wang HW, Wang HJ, Lan HY, Yang WH, Huang $\mathrm{CH}$, Kao SY, Tzeng CH, Tai SK, Chang SY, Lee OK, Wu KJ. Bmil is essential in
Twist1-induced epithelial-mesenchymal transition. Nature cell biology. 2010; 12:982-992.

21. Song LB, Li J, Liao WT, Feng Y, Yu CP, Hu LJ, Kong QL, Xu LH, Zhang X, Liu WL, Li MZ, Zhang L, Kang TB, Fu LW, Huang WL, Xia YF, et al. The polycomb group protein Bmi-1 represses the tumor suppressor PTEN and induces epithelial-mesenchymal transition in human nasopharyngeal epithelial cells. The Journal of clinical investigation. 2009; 119:3626-3636.

22. Wellner U, Schubert J, Burk UC, Schmalhofer O, Zhu F, Sonntag A, Waldvogel B, Vannier C, Darling D, zur Hausen A, Brunton VG, Morton J, Sansom O, Schuler J, Stemmler MP, Herzberger C, et al. The EMTactivator ZEB1 promotes tumorigenicity by repressing stemness-inhibiting microRNAs. Nature cell biology. 2009; 11:1487-1495.

23. Fujita N, Jaye DL, Kajita M, Geigerman C, Moreno CS, Wade PA. MTA3, a Mi-2/NuRD complex subunit, regulates an invasive growth pathway in breast cancer. Cell. 2003; 113:207-219.

24. Moggs JG, Murphy TC, Lim FL, Moore DJ, Stuckey R, Antrobus K, Kimber I, Orphanides G. Anti-proliferative effect of estrogen in breast cancer cells that re-express ERalpha is mediated by aberrant regulation of cell cycle genes. Journal of molecular endocrinology. 2005; 34:535-551.

25. Batlle E, Sancho E, Franci C, Dominguez D, Monfar M, Baulida J, Garcia De Herreros A. The transcription factor snail is a repressor of E-cadherin gene expression in epithelial tumour cells. Nature cell biology. 2000; 2:84-89.

26. Comijn J, Berx G, Vermassen P, Verschueren K, van Grunsven L, Bruyneel E, Mareel M, Huylebroeck D, van Roy F. The two-handed $\mathrm{E}$ box binding zinc finger protein SIP1 downregulates E-cadherin and induces invasion. Molecular cell. 2001; 7:1267-1278.

27. Cano A, Perez-Moreno MA, Rodrigo I, Locascio A, Blanco MJ, del Barrio MG, Portillo F, Nieto MA. The transcription factor snail controls epithelial-mesenchymal transitions by repressing E-cadherin expression. Nature cell biology. 2000; 2:76-83.

28. Bolos V, Peinado H, Perez-Moreno MA, Fraga MF, Esteller M, Cano A. The transcription factor Slug represses E-cadherin expression and induces epithelial to mesenchymal transitions: a comparison with Snail and E47 repressors. Journal of cell science. 2003; 116:499-511.

29. Yang JY, Zong CS, Xia W, Wei Y, Ali-Seyed M, Li Z, Broglio K, Berry DA, Hung MC. MDM2 promotes cell motility and invasiveness by regulating E-cadherin degradation. Molecular and cellular biology. 2006; 26:7269-7282.

30. Sobrado VR, Moreno-Bueno G, Cubillo E, Holt LJ, Nieto MA, Portillo F, Cano A. The class I bHLH factors E2-2A and E2-2B regulate EMT. Journal of cell science. 2009; 122:1014-1024. 
31. Wong AS, Gumbiner BM. Adhesion-independent mechanism for suppression of tumor cell invasion by E-cadherin. The Journal of cell biology. 2003; 161:1191-1203.

32. Guo BH, Feng Y, Zhang R, Xu LH, Li MZ, Kung HF, Song LB, Zeng MS. Bmi-1 promotes invasion and metastasis, and its elevated expression is correlated with an advanced stage of breast cancer. Molecular cancer. 2011; 10:10.

33. Beato M, Herrlich P, Schutz G. Steroid hormone receptors: many actors in search of a plot. Cell. 1995; 83:851-857.

34. Petz LN, Nardulli AM. Sp1 binding sites and an estrogen response element half-site are involved in regulation of the human progesterone receptor A promoter. Molecular endocrinology. 2000; 14:972-985.
35. Wang H, Liu H, Li X, Zhao J, Zhang H, Mao J, Zou Y, Zhang H, Zhang S, Hou W, Hou L, McNutt MA, Zhang B. Estrogen receptor alpha-coupled Bmil regulation pathway in breast cancer and its clinical implications. BMC cancer. 2014; 14:122.

36. Zhang D, Xie X, Chen Y, Hammock BD, Kong W, Zhu Y. Homocysteine upregulates soluble epoxide hydrolase in vascular endothelium in vitro and in vivo. Circulation research. 2012; 110:808-817.

37. Yang $\mathrm{MH}$, Chang SY, Chiou SH, Liu CJ, Chi CW, Chen PM, Teng SC, Wu KJ. Overexpression of NBS1 induces epithelial-mesenchymal transition and co-expression of NBS1 and Snail predicts metastasis of head and neck cancer. Oncogene. 2007; 26:1459-1467. 